\title{
PEMBERDAYAAN INDUSTRI KREATIF KERAJINAN PERAK MELALUI PENINGKATAN TEKNOLOGI TEPAT GUNA MESIN GILING PERAK
}

\section{Empowerment of Silver Creative Industries Through Improving Appropriate Technology Using Silver Milling Machines}

\author{
I Wayan Joniarta ${ }^{1}$, I Made Adi Sayoga ${ }^{1}$, Made Wijana ${ }^{1}$, I Gusti Agung \\ Ketut Chatur Adhi Wirya Aryadi ${ }^{1}$, Ni Ketut Surasni ${ }^{2}$ \\ ${ }^{1}$ Program Studi Teknik Mesin Universitas Mataram, ${ }^{2}$ Program Studi Ekonomi Manajemen \\ Universitas Mataram \\ Jalan Majapahit No 62, Kota Mataram Provinsi NTB \\ *Alamat Korespondensi: wayanjoniarta@unram.ac.id
}

(Tanggal Submission: 20 Oktober 2020, Tanggal Accepted: 28 Desember 2020)

\begin{abstract}
ABSTRAK
Desa Ungga, Kecamatan Praya Barat Daya, Lombok Tengah, merupakan sentra kerajinan perak. Produk yang dihasilkan adalah bros, cincin, giwang, tusuk konde, suweng, liontin dan gelang. Bahan utama produk perhiasan ini yaitu perak yang dicetak,digiling, diukir kemudian di kombinasi dengan kulit kerang, mutiara dan batu permata. Salah satu UKM yang menjadi mitra kegiatan pengabdian kepada masyarakat adalah "JEN's " Creative Silver. Permasalahan mitra yaitu masih menggunakan mesin giling manual yang diputar dengan tangan sehingga karyawan cepat lelah. Tujuan dari kegiatan ini yaitu menyediakan mesin penggiling perak dengan penggerak motor listrik yang nyaman dilengkapi dengan gearbox. Metode pelaksanaan yaitu mendesain, merancang dan merakit, melatih karyawan, menyediakan panduan perawatan mesin. Hasil kegiatan yaitu 1 unit mesin penggiling perak dengan penggerak motor Listrik 1 HP putaran $1450 \mathrm{rpm}$, terhubung gearbox 1:20 sehingga putaran rol penggiling sekitar $100 \mathrm{rpm}$. Mesin ini bisa membentuk kawat dengan diamater bervariasi mulai $2 \mathrm{~mm}$ hingga paling kecil sekitar 0,05 mm. Mesin ini mempunyai beberapa kelebihan yaitu,, putaran stabil, hasil giling bisa seragam dan karyawan tidak cepat lelah. Motor listrik yang di gunakan dilengkapi dengan switch otomatis yang akan memutus aliran listrik ketika terjadi konslet. Pengujian kinerja mesin, saat masih menggunakan mesin manual memerlukan waktu sekitar 10 sampai 15 menit untuk menggiling perak satu on (100 gr) sekarang menggunakan motor listrik, maka waktu bisa lebih cepat rata-rata $>50 \%$ bisa sampai $5-7$ menit untuk 1 on (100 gr). Peningkatan omzet sejak diterapkan mesin giling perak saat ini masih kecil,sekitar $3 \%$ akibat sepinya permintaan di tengah-tengah wabah pandemic covid-19.
\end{abstract}

Kata Kunci : Kerajinan perak, ungga, mesin giling 


\section{PENDAHULUAN}

Desa Ungga, Kecamatan Praya Barat Daya, Lombok Tengah, berkembang sebagai sentra kerajinan perak yang cukup terkenal. Bros, cincin, giwang, tusuk konde, suweng (sejenis giwang), liontin, gelang, dan brosliontin adalah produk perajin desa. Lokasi mitra berjarak 12 km selatan Praya, ibu kota Lombok Tengah ini dan 26,1 km dari Universitas Mataram.. Produk perhiasan berbahan utama perak ukiran, dicetak di kombinasi dengan cangkang kerang mutiara, batu permata, mutiara air laut maupun air tawar yang dibentuk jadi oval, bundar, lonjong, segiempat, segitiga, dan setengah bundar. Menurut Jaelani dan Farid, tokoh perajin desa itu, desain perhiasan itu merupakan ide kreatif perajin, selain desain para pemesan atau pemilik art shop di kawasan wisata Senggigi dan Kota Mataram. Hasil desain perajin desa ini jadi andalan daerah dalam event pameran tingkat regional dan nasional. Pengusaha yang membawa produk desain perajin itu sering memenangi lomba di pameran itu. Harga jual kerajinan desa ini bervariasi, cincin yang dihiasi mutiara seharga $\mathrm{Rp}$ 150.000-Rp 200.000 per buah, atau bros-liontin Rp 500.000Rp 2 juta per buah. Mitra Program Pengembangan Produk Unggulan Daerah (PPPUD) yaitu "JEN's" Creative Silver, dengan pemilik Pak Jaelani. Produk dari "JEN's" Creative Silver telah terdaftar di Depkumham sebagai produk yang dilindungi pada tahun 2017 dan pemilik UKM juga sudah mendapatkan penghargaan dari kementrian perindustrian tahun 2017.

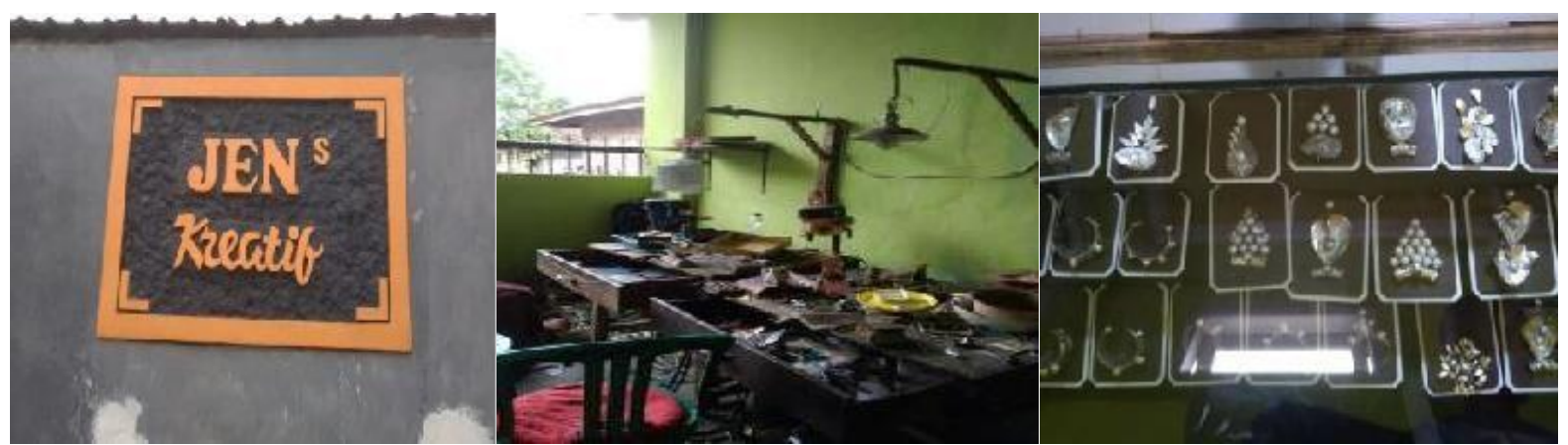

Gambar 1. Keterangan dari kiri ke kanan : Papan Nama UKM, Suasana Tempat Kerja UKM, Produk yang dihasilkan

Desa Ungga termasuk kawasan strategis karena letaknya di jalur transportasi Bandara Internasional Lombok (BIL) menuju kota Mataram dan kawasan wisata Pantai Kuta yang terkenal di Kabupaten Lombok Tengah. Permasalahan yang di tangani dalam kegiatan ini yaitu proses produksi, dalam hal ini teknologi proses dari yang sebelumnya alat giling manual ditingkatkan menjadi mesin giling perak berpenggerak motor listrik dengan transmisi gearbox. Adhi et al., (2017) memberikan solusi untuk peningkatan produktifitas usaha dan kenyamanan karyawan perlu dilakukan perbaikan dan peningkatan alat-alat produksi diantaranya alat penggiling perak. Tujuan kegiatan pengabdian kepada masyarakat ini adalah untuk menyediakan mesin penggiling perak yang di gerakkan dengan motor listrik $1 \mathrm{hp}$ dihubungkan dengan transmisi gearbox dengan rasio 1:20 untuk mendapatkan putaran mesin giling yang stabil ketika dipakai untuk bekerja. Dalam bidang manajemen juga bertujuan peningkatan kemampuan UKM dalam pegelolaan usaha dengan perbaikan pada system pembukuan dan pembuatan laporan keuangan 


\section{METODE KEGIATAN}

Metode yang dipakai dalam kegiatan ini yaitu perancangan, pembelian komponen, pengerjaan dan perakitan mesin, uji kinerja, sosialisasi, pelatihan serah terima dan pendampingan. Rangkaian kegiatan dalam metode pelaksanaan yang telah dilakukan.

1. Mempersiapkan desain / gambar mesin giling perak yang dilengkapi gearbox dan motor listrik (Gambar 4)

2. Menghitung kekuatan rancangan, dengan memperhatikan ketebalan bahan yang akan dibeli serta kwalitas bahan, seperti Baja Galvanis, baja profil C.
3. Pembelian bahan dan komponenkomponen yang diperlukan untuk pembuatan mesin giling perak, pembelian beberapa bahan bisa langsung disekitar Mataram, dan pembelian online untuk komponen yang tidak tersedia di Mataram

4. Pembuatan rangka dan perakitan di lab.produksi Jurusan Teknik Mesin Fakultas Teknik Unram

5. Uji Kinerja oleh tim pelaksana dan oleh pemilik UKM yang diundang datang ke kampus.

6. Sosialisasi dan pelatihan penggunaan mesin

7. Penyerahan TTG ke pemilik UKM.

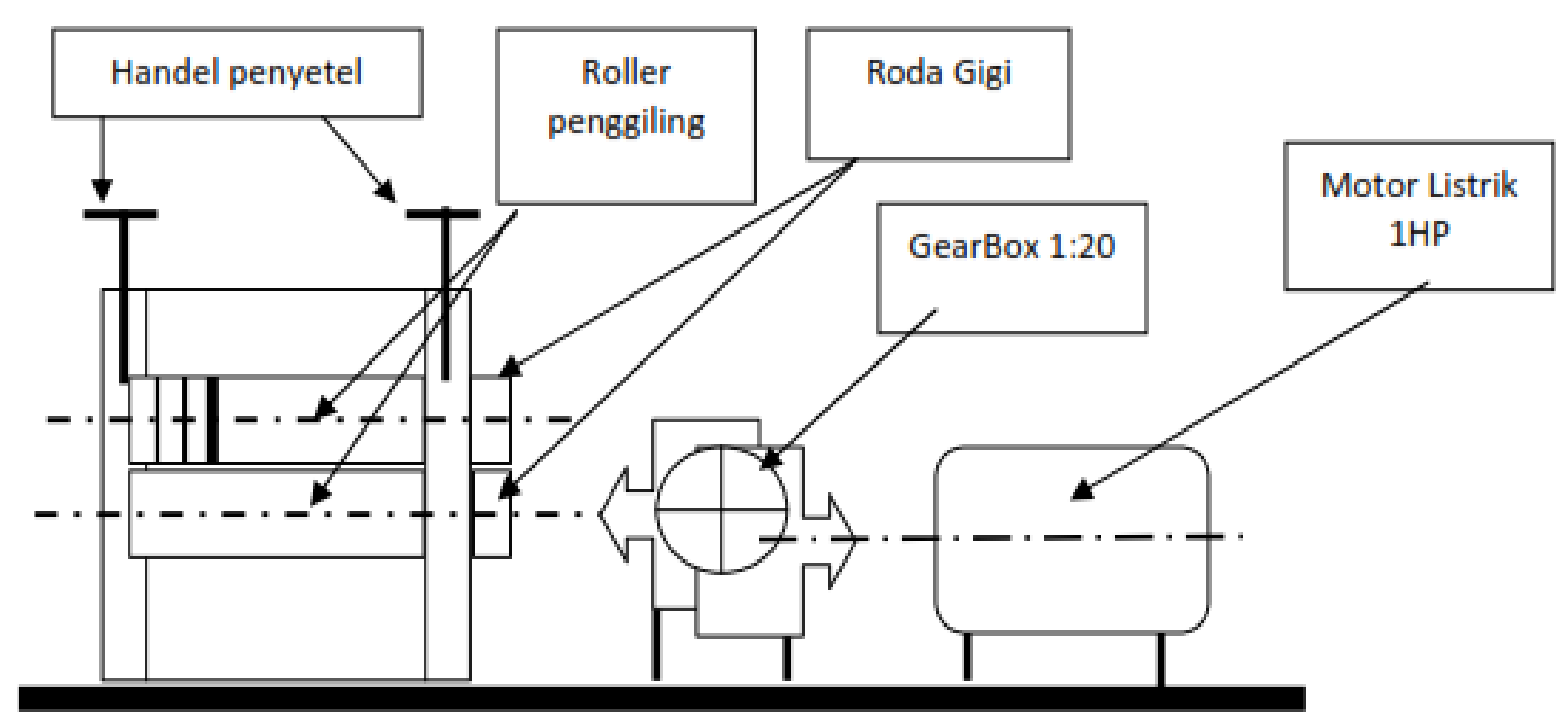

Gambar 2 Desain Mesin Penggiling Perak yang di gerakkan dengan Motor Listrik 
Cara kerja dari Mesin Giling ini : yaitu Motor Listrik akan memutar gear box dengan sambungan kopling kaku, gera box akan menurunkan putaran menjadi 100 rpm, sehingga putaran menjadi lambat, dari gear box putaran akan diteruskan dengan roda gigi menuju mesin giling dengan rasio gigi 1:2 sehingga putaran di mesin giling menjadi 200 rpm dengan karyawan yang bekerja tingga menyetel rol penekan untuk mengatur jarak celah dari rol mesin giling pada saat melakukan pembuatan perak bulat maupun perak pipih.

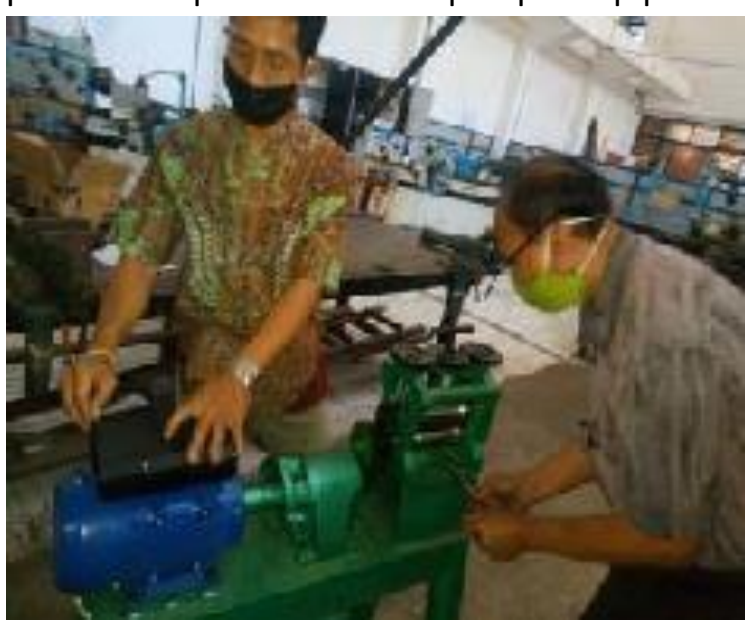

Gambar 3 Tim Pengabdian Sedang Merakit Komponen Mesin Giling Dan Mencoba Menjalankan

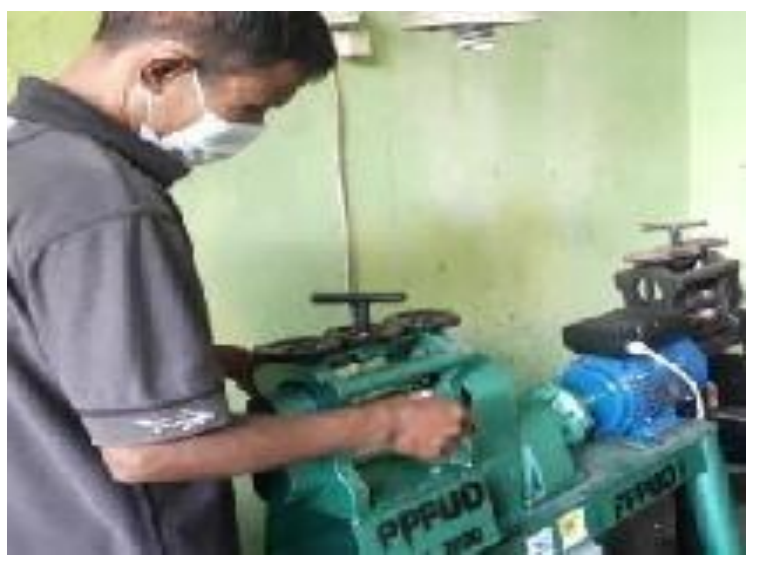

Gambar 4 Pemilik Ukm Sedang Mencoba Bekerja Dengan Mesin Giling Perak Yang Baru

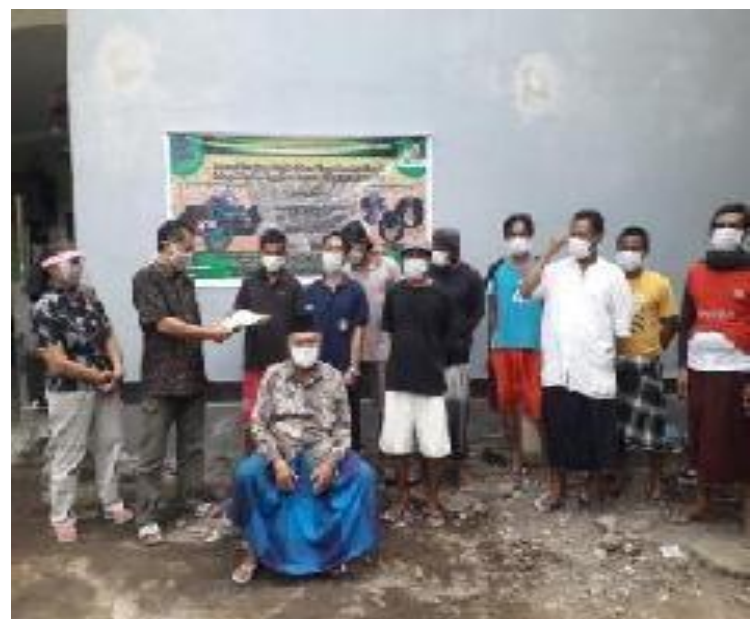

Gambar 5 Penyerahan Mesin Giling Kepada Pemilik UKM JEN's Silver Pak Jaelani Di Saksikan Oleh Karyawan Dan Tokoh Masyarakat Setempat

\section{HASIL DAN PEMBAHASAN}

Mesin giling perak baru yang diberikan memiliki dimensi yaitu Tinggi dari lantai $75 \mathrm{~cm}$, Panjang rangka $120 \mathrm{~cm}$ lebar rangka $60 \mathrm{~cm}$ dengan posisi rangka mengecil ke atas dengan lebar bagian atas sekitar $35 \mathrm{~cm}$. Keunggulan kinerja antara lain: berputar secara otomatis sehingga tidak perlu tenaga manusia lagi, karyawan bisa focus ketika menggiling perak, karyawan tidak cepat lelah sehingga suasana kerja menjadi lebih nyaman, mesin tahan panas, ada swicht otomatis ketika terjadi gangguan listrik atau ketika rol bekerja terlalu berat, ketika sudah dalam posisi normal maka swicht tinggal di tarik kembali untuk menghidupkan. Dari hasil kegiatan sudah dilakukan uji kinerja terhadap mesin giling perak Gambar 5 dan gambar 6 di atas yang dihasilkan dari program. Hasil pengujian di tampilakan dalam Tabel 1 berikut 
Tabel 1. Data hasil pengujian kinerja mesin giling perak kondisi sebelum dan sesudah penerapan

\begin{tabular}{lll}
\hline No & $\begin{array}{l}\text { Dengan } \\
\text { menggunakan } \\
\text { mesin manual }\end{array}$ & $\begin{array}{l}\text { Dengan } \\
\text { penggerak } \\
\text { Motor listrik + } \\
\text { Gearbox }\end{array}$ \\
\hline \multirow{2}{*}{$\begin{array}{l}\text { Untuk menggiling } \\
\text { 1 ons (100 gram }\end{array}$} & $\begin{array}{l}\text { Untuk } \\
\text { menggiling 1 ons } \\
\text { perak di butuhkan }\end{array}$ & $\begin{array}{l}\text { (100 gram perak } \\
\text { di butuhkan }\end{array}$ \\
& waktu 10 -15 & waktu 5 - 7 \\
& menit & menit \\
\hline
\end{tabular}

Tabel 1 menunjukkan terjadi peningkatan kecepatan penggilingan perak $2 \mathrm{x}$ lebih cepat dari proses kerja sebelumnya dengan menggunakan alat penggiling perak yang digerakkan secara manual. Mesin sudah dinyatakan siap di gunakan kemudain dikirim ke tempat UKM, untuk bisa digunakan bekerja secara penuh. Dampak Ekonomi dan Sosial berupa peningkatan produktifitas pada mitra dilaporkan dalam bentuk data terukur dan dapat disajikan dalam bentuk tabel 2 sehingga terlihat peningkatannya (keadaan mitra sebelum dan sesudah kegiatan.

Tabel 2. Data hasil peningkatan produktifitas sebelum dan sesudah aplikasi mesin giling perak

\begin{tabular}{lll}
\hline No & Dengan & Dengan \\
& menggunakan & penggerak Motor \\
& mesin manual & listrik + Gearbox \\
\hline 1 & Jumlah produksi & Jumlah produksi \\
& perhari 10-15 & meningkat \\
& pcs untuk produk & perhari 20-25 \\
& yang sudah biasa & pcs untuk produk \\
& & yang sudah biasa \\
\hline 2 & Karyawan cepat & Karyawan tidak \\
& lelah dalam & cepat lelah \\
& bekerja karena & dalam bekerja \\
& sambil memutar \\
& mesin giling & karena tidak \\
& & \\
\hline
\end{tabular}

\begin{tabular}{|c|c|c|}
\hline & & $\begin{array}{l}\text { perlu memutar } \\
\text { mesin giling lagi }\end{array}$ \\
\hline 3 & $\begin{array}{l}\text { Hasil pekerjaan } \\
\text { kurang halus, } \\
\text { karena putaran } \\
\text { mesin yang tidak } \\
\text { konstan }\end{array}$ & $\begin{array}{l}\text { Hasil kerjaan } \\
\text { menjadi lebih } \\
\text { halus karena } \\
\text { mesin berputar } \\
\text { secara konstan. }\end{array}$ \\
\hline 4 & $\begin{array}{l}\text { Pendapatan / } \\
\text { omzet UKM } \\
\text { sebelum aplikasi } \\
\text { mesin belum ada } \\
\text { peningkatan dari } \\
\text { sebelumnya }\end{array}$ & $\begin{array}{l}\text { Sudah ada } \\
\text { peningkatan } \\
\text { Omzet masih } 3 \\
\text { \%, itu di } \\
\text { sebabkan karena } \\
\text { permintaan akan } \\
\text { produk masih } \\
\text { sepi. }\end{array}$ \\
\hline
\end{tabular}

Kontribusi mitra sangat besar peranannya dalam menunjang pelaksanaan kegiatan PPPUD antara lain : ikut memberikan saran-saran dalam pemilihan mesin, menyediakan bahan baku untuk menguji kinerja mesin giling, mengundang perajinperajin disekitarnya untuk datang melihat saat penyerahan alat dan mesin. Mitra juga memperbaiki/ menambah plank nama UKM untuk penunjuk arah ke tempat UKM. UKM juga berkontribusi menyediakan tempat mencuci tangan untuk ikut menjaga kesehatan di masa pandemic covid-19.

\section{KESIMPULAN DAN SARAN}

\section{Kesimpulan}

Kegiatan ini sudah berhasil menyediakan mesin penggiling perak dengan penggerak motor listrik 1 HP dan transmisi gear box 1:20 untuk perajin perak JEN's Silver. Mesin sudah diserahkan kepada mitra UKM disaksikan langsung oleh karyawan dan tokoh masyarakat setempat. Keunggulan kinerja antara lain: berputar secara otomatis sehingga tidak perlu tenaga manusia lagi, karyawan bisa focus ketika menggiling perak, karyawan tidak cepat lelah sehingga suasana kerja menjadi lebih 
nyaman, mesin tahan panas,Mesin dilengkapi dengan sicth pengaman otomatis. Berdasarkan uji kinerja mesin giling perak maka didapatkan bahwa dengan pengadaan mesin giling perak ini mampu memberikan peningkatan kecepatan produksi sebesar lebih dari 50\% untuk proses penggilingan perak tiap-tiap 1 ons (100 gr) dari mesin manual yang di pakai selama ini, dengan demikian maka akan di dapatkan perubahan signifikan dalam produktifitas kerja meningkat 2 kali dari kondisi sebelumnya. Indikator omzet mitra juga mengalami kenaikan walupun belum besar hanya $3 \%$ dalam kondisi pandemi.

\section{Saran}

Kerjasama yang solid antara mitra dengan pelaksana akan menjamin lancarnya program pengabdian masyarakat yang dilaksana. Mitra UKM berkewajiban memelihara dan merawat mesin secara benar sehingga bisa berumur panjang. Peran dari pemilik dalam mencari peluang-peluang pasar sangat penting sehingga kegiatan usaha bisa berjalan lancer

\section{UCAPAN TERIMA KASIH}

Penulis menyampaikan ucapan terima kasih kepada Direktorat Riset dan Pengabdian Masyarakat, Direktorat Jenderal Penguatan Riset dan Pengembangan Kementrian Riset, Teknologi dan Pendidikan Tinggi . sesuai dengan Surat Perjanjian Penugasan Program Pengabdian Masyarakat. Nomor : 061/SP2H/PPM/DRPM/2020, tanggal 27
Februari 2020. Terima kasih juga kepada pihak LPPM Unram dan UKM JEN's Silver yang telah berkontribusi melancarkan program ini.

\section{DAFTAR PUSTAKA}

Aryadi, I.G.A.K.C.A.W., Wijana, M., \& Joniarta, I.W. (2017). Pengaruh Treatment Terhadap Peningkatan Produktivitas Industri Mikro/Kecil Sasaran (Export Oriented Product) Dalam Rangka Peningkatan Daya Saing Industri [Studi Kasus : Di Pulau Lombok-Ntb]. Dinamika teknik Mesin Vol. 7, No. 1, Juni 2017.

Sayoga, I.M.A., Joniarta, I.W., Aryadi, I.G.A.K.C.A.W., \& Surasni, N.K. (2020). Industri Kerajinan Perak di Desa Ungga Lombok Tengah Sebagai Produk Unggulan Daerah Penunjang Pariwisata. Jakarta : Kemenristekdikti.

Sayoga, I.M.A., Mirmanto, M., Susana, I.G.B., Mara, I.M., \& Joniarta, I.W. (2018). Sosialisasi Rancangan Ergonomi Mesin Poles Untuk Kerajinan Perak Di Desa Ungga, Kecamatan Praya Barat Daya, Kabupaten Lombok Tengah. Mataram : Universitas Mataram.

Sayoga, I.M.A., Mirmanto, M., Susana, I.G.B., Mara, I.M., \& Joniarta, I.W. (2019). Disain Meja Ergonomis Mesin Poles untuk Perajin Perak di Desa Ungga, Kecamatan Praya Barat Daya, Kabupaten Lombok Tengah. Karya Pengabdian Vol. 1 No 2 April 2019. 